\title{
INFLUENCE OF MAGNESIUM (Mg) SOURCE ON THE Cordyceps militaris (L.) MUSHROOM MYCELIUM GROWTH
}

\author{
Melinda Rózsa ${ }^{1}$, Dănuț-Nicolae Măniuțiu ${ }^{*}$, Emese Egyed ${ }^{1}$ \\ ${ }^{1}$ University of Agricultural Sciences and Veterinary Medicine, \\ Faculty of Horticulture, 400372, 3-5 Mănăştur Street, Cluj-Napoca, Romania
}

\begin{abstract}
Magnesium $(\mathrm{Mg})$ is an element with a role in oxidation processes. The optimal concentration of magnesium for the development of fungi is associated with an optimal concentration of phosphorus $(P)$, which through its essential constituents, is an important element for the existence of biological systems in nature through nucleic acids, phospholipids, phosphoglycerides, phytin and phosphates. Magnesium has a role in the activity of certain enzymes and in respiration, being a component of protein substances with a special importance for microorganisms being included in reducing and phosphorylating enzymes and for protein synthesis. In this study, magnesium sulphate (MgSO4), which is an accessible source of both magnesium and sulphur, as well as magnesium carbonate (MgCO3) were used as sources of magnesium, both being used in different concentrations in the growth medium. The culture medium or substrate influences the growth of the fungal mycelium, through the mineral, nutritive and stimulating substances in their composition. Using experimental culture media, an isolated tissue culture was performed from 2 strains of Cordyceps militaris (L.) fungus. The culture was performed in Petri dishes, incubated at a temperature of $24{ }^{\circ} C$, aiming to increase the mycelium for 15 days. The highest increase was recorded by strain CI 32 with the addition of magnesium sulphate.
\end{abstract}

Keywords: Cordyceps militaris (L.), magnesium, mushroom, mycelium.

\section{INTRODUCTION}

Mushrooms are a complete food with a high nutritional value, the chemical composition of mushrooms differs with the species, the stage of ontogenetic development, with different parts of the carposome (hat, leg) and the nutrient substrate on which they grow (Hoa and Wang, 2015; Rózsa, 2017a).

In general, mushrooms contain: $82-92 \%$ water, $0.5-1.5 \%$ mineral salts (potassium, calcium, magnesium, phosphorus, silicon), 1-3\% sugars (mannite, glucose, trehalose, glycogen and cellulose), 2-4\% nitrogenous substances (proteins), very low amounts of fats (1\% lecithin), tannins, organic acids (malic, citric, tartaric) and vitamins ( $\mathrm{A}$ in the form of carotene, $\mathrm{B}_{1}, \mathrm{~B}_{2}$ and $\mathrm{D}$ ) (Kalyoncu et al., 2010; Rózsa et al., 2016a; Rózsa et al., 2017b).

It is recommended that mushrooms be eaten at a young age and as soon as possible after harvest, as they contain easily altered substances. Mushrooms can be preserved fresh or preserved (dried, pickled or marinated) (Zhu et al., 1998; Rózsa et al., 2016b; Rózsa et al., 2017f). 
Ascomycetes are characterized by a well-developed vegetative apparatus, most fungi in this class have a filamentous stem, the mycelium being composed of multicellular hyphae often branched, isolated or anastomosed (Kalyoncu et al., 2010; Rózsa et al., 2016c; Rózsa et al., 2017c).

Their multiplication is asexual and is achieved by different spores (conidia, pycnospores).

Filamentous thallus is the most widespread vegetative apparatus of fungi. It is represented by simple or branched multicellular filaments, each compartment representing a cell. Both the siphonoplast and the filamentous thallus are also known as mycelium, and the filaments that make it up are called mycelial hyphae. The filamentous thallus is found in fungi of the class Ascomycetes, Basidiomycetes and the group Deuteromycetes (Patel and Ingalhalli, 2013; Rózsa et al., 2016d).

A culture medium can be defined as a sterile nutrient support, which allows the development and study of a microorganism outside the natural ecological niche. In order to allow the development of microorganisms, any culture medium must meet certain conditions: to contain nutrients necessary for metabolism, to have a certain $\mathrm{pH}$ reaction within which the fungus can grow, to correspond to the physiological characteristics of fungi, taking into account their type, breathing and be sterile.

For mother cultures and pure cultures in the laboratory, a liquid or solid culture medium containing all the minerals necessary for the growth of the mycelium is needed (Rózsa et al., 2016e).

The passage of the mycelium in the laboratory, from one culture medium to another, is important for keeping it in a viable state for as long as possible. Ironing is done every three months but can be performed even earlier. But if this is delayed a lot and the mycelium has nothing to feed on, it can perish. This is all the more important when we keep new, valuable stems that can no longer be reconstituted (Patel and Ingalhalli, 2013; Rózsa et al., 2016f).

The mineral elements with a role in the growth of the mycelium both on the laboratory culture medium and on the granular medium, i.e., the one based on cereals, but also on compost or lignocellulosic substrate are very important (Rózsa et al., 2019; Rathore et al., 2019).

Magnesium $(\mathrm{Mg})$ is an element with a role in oxidation processes. The optimal concentration of magnesium for the development of fungi is associated with an optimal concentration of phosphorus (P), which through its essential constituents, is an important element for the existence of biological systems in nature through nucleic acids, phospholipids, phosphoglycerides, phytin and phosphates. Magnesium has a role in the activity of certain enzymes and in respiration, being a component of protein substances with a special importance for microorganisms being included in reducing and phosphorylating enzymes and for protein synthesis (Wang and Shiao, 2000; Rózsa et al., 2016g).

Through its essential constituents, phosphorus $(\mathrm{P})$ is an important element for the existence of biological systems in nature, through nucleic acids, phospholipids, phosphoglycerides, phytin and phosphates (Xiao and Zhong, 2007; Rózsa et al., 2016h). Phosphorus is found in organic waste in the form of organic compounds. Soluble phosphates are important nutrients for all biological systems (Rózsa et al., 2017d). The mineralization of organic compounds takes place under the action of enzymes such as: phytases, phosphatases, nucleases, phospholipases, glycerophosphatases, etc. secreted by various microorganisms. The mineralization process is activated by an alkaline $\mathrm{pH}$ and a temperature above $20^{\circ} \mathrm{C}$. By mineralizing the organic compounds with phosphorus, soluble orthophosphates are born, which can be used as nutrients by biological systems, plants, microorganisms, or insoluble phosphate is formed with calcium, magnesium, iron and aluminum. Immobilized forms of phosphorus in the form of insoluble phosphates, constitute a reserve of nutrients and can be enhanced by their solubilization, calcium intake having an essential role in this case (Yang et al., 1994; Rózsa et al., 2017e). 
In this study, magnesium sulphate $\left(\mathrm{MgSO}_{4}\right)$, which is an accessible source of both magnesium and sulphur, as well as magnesium carbonate $\left(\mathrm{MgCO}_{3}\right)$ were used as sources of magnesium, both being used in different concentrations in the growth medium.

\section{MATERIALS AND METHODS}

Magnesium sulphate $\left(\mathrm{MgSO}_{4}\right)$ is a salt of sulfuric acid with magnesium, having a molar mass of $120.37 \mathrm{~g} / \mathrm{mol}$ and a density of $2.66 \mathrm{~g} / \mathrm{cm}^{3}$, being a water-soluble substance $\left(269 \mathrm{~g} / \mathrm{L}\left(0{ }^{\circ} \mathrm{C}\right)\right)$ MgSO4 - 7H2O: $710 \mathrm{~g} / \mathrm{L}\left(20^{\circ} \mathrm{C}\right)$, used as a chemical fertilizer in agriculture, serving as a source of magnesium for plants (S1 experimental variant).

Magnesium carbonate $\left(\mathrm{MgCO}_{3}\right)$ is magnesium salt with carbonic acid, having a molar mass of $84.31 \mathrm{~g} \mathrm{/} \mathrm{mol} \mathrm{and} \mathrm{a} \mathrm{density} \mathrm{of} 2.96 \mathrm{~g} / \mathrm{cm}^{3}\left(20^{\circ} \mathrm{C}\right)$, being a poorly soluble substance in water $(0.106$ $\mathrm{g} / \mathrm{L})$. Magnesium carbonate, which is chemically neutral, is converted by heat release hydration into basic magnesium carbonate and determines the hardness of the water ( $\mathrm{S} 2$ experimental variant). The biological material used in the experiment was represented by 2 similar strains of the Cordyceps militaris (L.) fungus, CI 32 and CI 44, from pure cultures from the Ciupercaria SRL company, from Aghireșu-Fabrici, Cluj County (T1 and T2 experimental variants).

The culture medium used was PDA (potato-dextrose-agar), being the most used medium in mycology, being favorable for the growth of most fungi. The medium was prepared from $200 \mathrm{~g}$ potatoes, $20 \mathrm{~g}$ dextrose, $20 \mathrm{~g}$ agar and $1000 \mathrm{ml}$ distilled water, to which were added different concentrations of magnesium salts $(1 \mathrm{~g}, 3 \mathrm{~g}$ and $5 \mathrm{~g} \rightarrow \mathrm{C} 1, \mathrm{C} 2$ and $\mathrm{C} 3$ experimental variants).

To prepare the medium, the potatoes were washed and cleaned, and then cut into cubes of about 12 $\mathrm{mm}$. Weighed $200 \mathrm{~g}$ of peeled potatoes, rinsed in water and boiled in a glass bowl for one hour, until the potatoes were softened and crushed. Strain as much pulp as possible through the gauze, then we add the agar and boil until it has dissolved. It was set on fire; dextrose was added and mixed until dissolved. Make up to 1 liter with distilled water, then was sterilize at $121{ }^{\circ} \mathrm{C}$ for 15 minutes. The culture medium was poured into sterile Petri dishes under a sheet flow hood. During casting, the culture medium was stirred continuously so that the distributed medium was uniform. The mycelium increase was recorded daily and the obtained results are presented in millimeters over 15 days of growth (Rózsa et al., 2019).

The combination of experimental factors resulted in 12 experimental variants. The results obtained were interpreted statistically, using the Statistica 10 program.

\section{RESULTS AND DISCUSSIONS}

In table 1 are presented the results on the unilateral influence of strain (T) on the growth of the $\mathrm{C}$. militaris L. mushroom mycelium.

Table 1. The unilateral influence of strain (T) on the growth of the C. militaris L. mushroom mycelium

\begin{tabular}{|c|c|c|c|c|}
\hline \multirow{2}{*}{ Experimental variant } & \multicolumn{2}{|c|}{ Mycelial growth(mm)/15 days } & Difference (mm) & Signification of difference \\
\cline { 2 - 3 } & Obtained values & $\mathbf{\%}$ & -4.19 & - \\
\hline T1 & 41.23 & 90.8 & 4.18 & - \\
\hline T2 & 49.60 & 109.2 & 0.00 & Avg. \\
\hline Average & 45.41 & 100.0 & 7.16 & \\
\hline \multicolumn{4}{|c}{ LSD (p 5\%) } \\
LSD (p 1\%) & 35.86 & \\
LSD (0.1\%) & 358.63 & \\
\end{tabular}




\section{Current Trends in Natural Sciences}

Vol. 10, Issue 19, pp. 333-340, 2021

https://doi.org/10.47068/ctns.2021.v10i19.043

Current Trends in Natural Sciences (on-line)

Following the results presented in above table, it can be seen that none of the studied strains show statistically assured results, regarding the source of magnesium used. However, the analyzed T2 strain, registered for the 15 days an increase of $49.60 \mathrm{~mm}$, the experience average being $45.41 \mathrm{~mm}$ for 15 days.

In table 2 are presented the results on the unilateral influence of magnesium source (S) on the growth of the C. militaris L. mushroom mycelium during the experience.

Table 2. The unilateral influence of magnesium source $(S)$ on the growth of the C. militaris L. mushroom mycelium

\begin{tabular}{|c|c|c|c|c|}
\hline \multirow{2}{*}{ Experimental variant } & \multicolumn{2}{|c|}{ Mycelial growth(mm)/15 days } & Difference (mm) & Signification of difference \\
\cline { 2 - 5 } & Obtained values & $\mathbf{\%}$ & $\mathbf{\pm D}$ & $* *$ \\
\hline S1 & 57.59 & 126.8 & 12.18 & 00 \\
\hline S2 & 33.23 & 73.2 & -12.16 & Avg. \\
\hline Average & 45.41 & 100.0 & 0.00 & \\
\multicolumn{5}{r}{ LSD (p 5\%) } \\
LSD (p 1\%) & 8.85 & \\
LSD (0.1\%) & 28.28 & \\
\end{tabular}

Following the results presented in above table, it can be seen that the $\mathrm{S} 1$ magnesium source $\left(\mathrm{MgSO}_{4}\right)$, registered $12.18 \mathrm{~mm}$ difference from the experience average, the result being significantly positive, compared to the experience average considered as control. For the S2 magnesium source $\left(\mathrm{MgCO}_{3}\right)$ registered a significantly negative difference.

Table 3 presents the result on the unilateral influence of magnesium source concentration $(\mathrm{C})$ on the growth of the $C$. militaris L. mushroom mycelium.

Table 3. The unilateral influence of magnesium source concentration $(C)$ on the growth of the C. militaris L. mushroom mycelium

\begin{tabular}{|c|c|c|c|c|}
\hline \multirow{2}{*}{ Experimental variant } & \multicolumn{2}{|c|}{ Mycelial growth(mm)/15 days } & \multirow{2}{*}{$\begin{array}{c}\text { Difference }(\mathrm{mm}) \\
\pm \mathrm{D}\end{array}$} & \multirow{2}{*}{ Signification of difference } \\
\hline & Obtained values & $\%$ & & \\
\hline $\mathrm{C} 1$ & 46.21 & 101.8 & 0.80 & - \\
\hline $\mathrm{C} 2$ & 50.16 & 110.4 & 4.74 & $* *$ \\
\hline $\mathrm{C} 3$ & 39.87 & 87.8 & -5.54 & 00 \\
\hline Average & 45.41 & 100.0 & 0.00 & Avg. \\
\hline & $\begin{array}{l}\operatorname{LSD}(p 5 \% \\
\operatorname{LSD}(p 1 \% \\
\operatorname{LSD}(0.1 \%\end{array}$ & & $\begin{array}{l}2.66 \\
3.87 \\
5.81\end{array}$ & \\
\hline
\end{tabular}

Analyzing the concentration of the used magnesium source, the results obtained highlighted the $\mathrm{C} 2$ concentration, being the most optimal for our experience.

For this experimental variant, we recorder $50.16 \mathrm{~mm}$ mycelial growth per 15 days of experience, the result being significantly positive, compared to the experience average considered as control 45.41 mm per 15 days.

For $\mathrm{C} 1$ experimental variant, the obtained results, $46.21 \mathrm{~mm}$ mycelial growth per 15 days, were not statistically assured. C3 experimental variant, registered $39.87 \mathrm{~mm}$ mycelial growth per 15 days, the result being significantly negative, compared to the experience average considered as control. 


\section{Current Trends in Natural Sciences}

Vol. 10, Issue 19, pp. 333-340, 2021

https://doi.org/10.47068/ctns.2021.v10i19.043

Current Trends in Natural Sciences (on-line)

During the course of the experiment was followed the combined influence of factors magnesium source $(\mathrm{S})$ and its concentration $(\mathrm{C})$ used on the growth of the mycelium of the C. militaris L. mushroom, the data obtained are presented in table 4.

Table 4. The combined influence of factors magnesium source $(S)$ and its concentration $(C)$ used on the growth of the mycelium of the C. militaris L. mushroom

\begin{tabular}{|c|c|c|c|c|}
\hline \multirow{2}{*}{ Experimental variant } & \multicolumn{2}{|c|}{ Mycelial growth(mm)/15 days } & \multirow{2}{*}{$\begin{array}{c}\text { Difference }(\mathbf{m m}) \\
\pm \mathrm{D}\end{array}$} & \multirow{2}{*}{ Signification of difference } \\
\hline & Obtained values & $\%$ & & \\
\hline S1 C1 & 58.91 & 127.5 & 12.70 & ** \\
\hline $\mathrm{S} 2 \mathrm{C} 1$ & 33.51 & 72.5 & -12.68 & 00 \\
\hline Average & 46.21 & 100.0 & 0.00 & Avg. \\
\hline $\mathrm{S} 1 \mathrm{C} 2$ & 63.21 & 126.0 & 13.06 & $* *$ \\
\hline $\mathrm{S} 2 \mathrm{C} 2$ & 37.10 & 74.0 & -13.02 & 00 \\
\hline Average & 50.16 & 100.0 & 0.00 & Avg \\
\hline S1 C3 & 50.67 & 50.67 & 10.79 & $* *$ \\
\hline S2 C3 & 29.08 & 29.08 & -10.77 & 00 \\
\hline Average & 39.87 & 100.0 & 0.00 & Avg. \\
\hline & $\begin{array}{l}\text { LSD }(p 5 \% \\
\text { LSD (p 1\% } \\
\text { LSD }(0.1 \%\end{array}$ & & $\begin{array}{c}4.70 \\
8.67 \\
21.35\end{array}$ & \\
\hline
\end{tabular}

The combined influence of factors magnesium source $(\mathrm{S})$ and its concentration $(\mathrm{C})$ used on the growth of the mycelium of the C. militaris L. mushroom, they highlighted S1 magnesium source $\left(\mathrm{MgSO}_{4}\right)$, this registering significantly positive differences, regardless of the concentration to which it was applied (C1, C2 or C3). In this case, mycelial growth recorded values between 50.67 and $63.21 \mathrm{~mm}$ per 15 days of experiment. The data obtained by us are comparable to those found in the scientific literature.

In table 5 are presented the values obtained for the combined influence of factors, magnesium source $(\mathrm{S})$ and the used mycelium strain $(\mathrm{T})$ on the growth of the of the $C$. militaris L. mushroom mycelium.

Table 5. The combined influence of factors magnesium source (S) and the used mycelium strain (T) on the growth of the of the C. militaris L. mushroom mycelium

\begin{tabular}{|c|c|c|c|c|}
\hline \multirow{2}{*}{ Experimental variant } & \multicolumn{2}{|c|}{ Mycelial growth(mm)/15 days } & \multirow{2}{*}{$\begin{array}{c}\text { Difference }(\mathrm{mm}) \\
\pm \mathrm{D}\end{array}$} & \multirow{2}{*}{ Signification of difference } \\
\hline & Obtained values & $\%$ & & \\
\hline $\mathrm{S} 1 \mathrm{~T} 1$ & 53.00 & 128.6 & 11.74 & $*$ \\
\hline $\mathrm{S} 2 \mathrm{~T} 1$ & 29.46 & 71.4 & -11.76 & 0 \\
\hline Average & 41.23 & 100.0 & 0.00 & Avg. \\
\hline $\mathrm{S} 1 \mathrm{~T} 2$ & 62.19 & 125.4 & 12.57 & $* *$ \\
\hline S2 T2 & 37.01 & 74.6 & -12.59 & 00 \\
\hline Average & 49.60 & 100.0 & 0.00 & Avg \\
\hline & $\begin{array}{l}\text { LSD (p 5\% } \\
\operatorname{LSD}(\mathrm{p} 1 \% \\
\operatorname{LSD}(0.1 \%\end{array}$ & & $\begin{array}{c}5.44 \\
12.57 \\
39.99\end{array}$ & \\
\hline
\end{tabular}




\section{Current Trends in Natural Sciences}

Vol. 10, Issue 19, pp. 333-340, 2021

https://doi.org/10.47068/ctns.2021.v10i19.043

Current Trends in Natural Sciences (on-line)

ISSN: 2284-953X

Current Trends in Natural Sciences (CD-Rom)

ISSN: 2284-9521

ISSN-L: 2284-9521

ISSN-L: 2284-9521

Following the data in the table above, for the S1 T2 experimental variant, we recorded $62.19 \mathrm{~mm}$ per 15 days mycelial growth, the result being significantly positive, compared to the experience average considered as control. For the S1 T1 experimental variant, we recorded $53.00 \mathrm{~mm}$ per 15 days mycelial growth, in this case the result being positive, compared to the experience average considered as control. For S2 T1 and S2 T2 experimental variants, we recorded negative and significantly negative differences, compared to the experience average considered as control.

Table 6 presents the obtained values for the combined influence of factors magnesium concentration $(\mathrm{C})$ and the used mycelium strain $(\mathrm{T})$ on the growth of the of the $C$. militaris L. mushroom mycelium in our experience.

Table 6. The combined influence of factors magnesium concentration (C) and the used mycelium strain (T) on the growth of the of the C. militaris L. mushroom mycelium

\begin{tabular}{|c|c|c|c|c|}
\hline \multirow{2}{*}{ Experimental variant } & \multicolumn{2}{|c|}{ Mycelial growth(mm)/15 days } & \multirow{2}{*}{$\begin{array}{c}\text { Difference }(\mathrm{mm}) \\
\pm \mathrm{D}\end{array}$} & \multirow{2}{*}{ Signification of difference } \\
\hline & Obtained values & $\%$ & & \\
\hline $\mathrm{C} 1 \mathrm{~T} 1$ & 44.58 & 108.1 & 3.35 & - \\
\hline $\mathrm{C} 2 \mathrm{~T} 1$ & 43.79 & 106.2 & 2.56 & - \\
\hline C3 T1 & 35.32 & 85.7 & -5.91 & 00 \\
\hline Average & 41.23 & 100.0 & 0.00 & Avg. \\
\hline $\mathrm{C} 1 \mathrm{~T} 2$ & 47.84 & 96.4 & -1.76 & - \\
\hline $\mathrm{C} 2 \mathrm{~T} 2$ & 56.52 & 114.0 & 6.92 & $* *$ \\
\hline C3 T2 & 44.43 & 89.6 & 5.16 & 0 \\
\hline Average & 49.60 & 100.0 & 0.00 & Avg. \\
\hline & $\begin{array}{l}\text { LSD }(p 5 \% \\
\text { LSD (p 1\% } \\
\text { LSD }(0.1 \%\end{array}$ & & $\begin{array}{l}3.77 \\
5.48 \\
8.22\end{array}$ & \\
\hline
\end{tabular}

The combined influence of factors magnesium concentration $(\mathrm{C})$ and the used mycelium strain $(\mathrm{T})$ on the growth of the of the $C$. militaris $\mathrm{L}$. mushroom mycelium, highlight the $\mathrm{C} 2 \mathrm{~T} 2$ experimental combination, with $56.52 \mathrm{~mm}$ growth per 15 days of experiment, the obtained result being distinctly significantly positive, compared to the experience average considered as control.

The C3 T1 and C3 T2 experimental combinations, register distinctly significantly negatively and negatively differences, compared to the experience average considered as control. For this combination of factors, we have also experimental combinations that did not record statistically assured data, like $\mathrm{C} 1 \mathrm{~T} 1, \mathrm{C} 2 \mathrm{~T} 1$ and $\mathrm{C} 1 \mathrm{~T} 2$.

Also, in this case the obtained data highlight the $\mathrm{C} 2$ concentration of magnesium supply.

Among the culture medium recipes found in the scientific literature, we can find also these concentrations of magnesium used by us during the experiment.

Taking into account that we have organized a three-factor experiment, the combination of the three factors was followed: magnesium source (S), mycelium strain (T) and magnesium concentration (C) on the growth of the of the C. militaris L. mushroom mycelium, the data obtained are presented in table 7 . 


\section{Current Trends in Natural Sciences}

Vol. 10, Issue 19, pp. 333-340, 2021

https://doi.org/10.47068/ctns.2021.v10i19.043

Current Trends in Natural Sciences (on-line)

Table 7. The combined influence of factors: magnesium source $(S)$, mycelium strain $(T)$ and magnesium concentration $(C)$ on the growth of the of the $C$. militaris $L$. mushroom mycelium

\begin{tabular}{|c|c|c|c|c|}
\hline \multirow{2}{*}{ Experimental variant } & \multicolumn{2}{|c|}{ Mycelial growth(mm)/15 days } & \multirow{2}{*}{$\begin{array}{c}\text { Difference }(\mathrm{mm}) \\
\pm \mathrm{D}\end{array}$} & \multirow{2}{*}{ Signification of difference } \\
\hline & Obtained values & $\%$ & & \\
\hline S1 T1 C1 & 56.19 & 126.0 & 11.59 & * \\
\hline S2 T1 C1 & 32.98 & 74.0 & -11.61 & 0 \\
\hline Average & 44.58 & 100.0 & 0.00 & Avg. \\
\hline S1 T1 C2 & 57.72 & 131.8 & 13.93 & $* *$ \\
\hline S2 T1 C2 & 29.87 & 68.2 & -13.92 & 00 \\
\hline Average & 43.79 & 100.0 & 0.00 & Avg. \\
\hline S1 T1 C3 & 45.11 & 127.7 & 9.78 & * \\
\hline S2 T1 C3 & 25.52 & 72.3 & -9.80 & 0 \\
\hline Average & 35.32 & 100.0 & 0.00 & Avg. \\
\hline $\mathrm{S} 1 \mathrm{~T} 2 \mathrm{C} 1$ & 61.63 & 128.8 & 13.80 & ** \\
\hline S2 T2 C1 & 34.04 & 71.2 & -13.78 & 00 \\
\hline Average & 47.84 & 100.0 & 0.00 & Avg. \\
\hline S1 T2 C2 & 68.71 & 121.6 & 12.19 & * \\
\hline $\mathrm{S} 2 \mathrm{~T} 2 \mathrm{C} 2$ & 44.34 & 78.4 & -12.17 & 0 \\
\hline Average & 56.52 & 100.0 & 0.00 & Avg. \\
\hline $\mathrm{S} 1 \mathrm{~T} 2 \mathrm{C} 3$ & 56.22 & 126.5 & 11.79 & * \\
\hline S2 T2 C3 & 32.65 & 73.5 & -11.77 & 0 \\
\hline Average & 44.43 & 100.0 & 0.00 & Avg. \\
\hline & $\begin{array}{l}\text { LSD }(p 5 \% \\
\text { LSD (p 1\% } \\
\text { LSD }(0.1 \%\end{array}$ & & $\begin{array}{c}6.65 \\
12.26 \\
30.19\end{array}$ & \\
\hline
\end{tabular}

Following the data in the table above, regarding the combined influence of factors, in this case, too, they highlight magnesium sulphate (S1) as the best source of magnesium in the C. militaris L. mushrooms culture medium, the recorded values being statistically assured, regardless of the concentration used or the mushroom strain. For magnesium carbonate (S2) we registered significantly negatively and negatively differences, compared to the experience average considered as control.

\section{CONCLUSIONS}

Based on the experimental results obtained on the complex influence of the magnesium source used in the culture medium of Cordyceps militaris L., the following can be concluded:

- the unilateral influence of the magnesium source used highlights magnesium sulphate, with statistically assured differences;

- the unilateral influence of the magnesium concentration used in the substrate recipe highlights the results obtained for the concentration of 3 grams.

\section{REFERENCES}

Hoa, H. T., \& Wang, C. L. (2015). The effects of temperature and nutritional conditions on mycelium growth of two oyster mushrooms (Pleurotus ostreatus and Pleurotus cystidiosus). Mycobiology, 43(1), 14-23.

Kalyoncu, F., Oskay, M., \& Kayalar, H. (2010). Antioxidant activity of the mycelium of 21 wild mushroom species. Mycology, 1(3), 195-199.

Patel, K. J., \& Ingalhalli, R. S. (2013). Cordyceps militaris (L.: Fr.) Link-An Important Medicinal Mushroom. Journal of Pharmacognosy and Phytochemistry, 2(1). 


\section{Current Trends in Natural Sciences}

Vol. 10, Issue 19, pp. 333-340, 2021

https://doi.org/10.47068/ctns.2021.v10i19.043

Current Trends in Natural Sciences (on-line)

ISSN: 2284-953X

Current Trends in Natural Sciences (CD-Rom)

ISSN: 2284-9521

ISSN-L: 2284-9521

ISSN-L: 2284-9521

Rathore, H., Prasad, S., Kapri, M., Tiwari, A., \& Sharma, S. (2019). Medicinal importance of mushroom mycelium: Mechanisms and applications. Journal of functional foods, 56, 182-193.

Rózsa S. (2017a). Correlation between soluble dry matter and $\beta-1,3$ d-glucan content in Agaricus blazei Murrill mushrooms, Lucrări Științifice - Seria Horticultură, USAMV Iași, Volume 60 (2), 131-138.

Rózsa S., Dănuț M.N., Gocan Tincuta-Marta, David Stela, Butuza-Bumb Felicia-Suzana (2016a). Dynamic of the Agaricus blazei Murrill mushroom mycelium growth, Journal of Horticulture, Forestry and Biotechnology, Volume 20(1), 120-122.

Rózsa S., Dănuţ M.N., Gocan Tincuta-Marta, David Stela, Butuza-Bumb Felicia-Suzana (2016b). Research on the biology of the Agaricus blazei Murrill mushroom mycelium, Journal of Horticulture, Forestry and Biotechnology, Volume 20(1), 123-126.

Rózsa S., Dănuț M.N., Gocan Tincuța-Marta, David Stela, Butuza-Bumb Susana-Felicia (2016c). Research on the influence of temperature on the growth of Agaricus blazei Murrill mushroom mycelium, Agriculture - Science and Practice Journal, Vol 97-98, No 1-2, 53-57.

Rózsa S., Dănuț M.N., Gocan Tincuța-Marta, David Stela, Butuza-Bumb Susana-Felicia (2016d). Influence of pasteurization on different composts used for Agaricus ssp. mushroom cultivation on changing the ammonia concentration and the pH level, Agriculture - Science and Practice Journal, Vol 99-100, No 3-4, 34-39.

Rózsa S., Dănuț M.N., Lazăr V., Gocan Tincuța-Marta, Andreica Ileana (2016e). The influence of pH and the source of nitrogen on the mycelial growth of the Pleurotus ostreatus mushrooms, Scientific works - Agronomy series, USAMV Iași, vol. 59(2), 243-246.

Rózsa S., Dănuț M.N., Lazăr V., Gocan Tincuța-Marta, Butuza-Bumb Susana-Felicia (2016f). The influence of culture technology on production and chemical content in Agaricus blazei Murrill mushrooms, Scientific works Agronomy series, USAMV Iași, vol. 59(2), 237-242.

Rózsa S., Dănuț M.N., Poșta G., Gocan Tincuța-Marta, Andreica Ileana, Bogdan Ileana, Rózsa Melinda, Lazăr V. (2019). Influence of the culture substrate on the Agaricus blazei Murrill mushrooms vitamins content, Plants, 8, 316, https://doi.org/10.3390/plants8090316

Rózsa S., Dănuț M.N., Sima Rodica, Gocan Tincuța-Marta, Andreica Ileana $(2016 \mathrm{~g})$. Research on the influence of hybrid, culture substrate and method of disinfection on oyster mushrooms - Pleurotus Spp., Scientific works Agronomy series, USAMV Iași, vol. 59(1), 35-38.

Rózsa S., Dănuț M.N., Sima Rodica, Gocan Tincuţa-Marta, Butuza-Bumb Susana-Felicia (2016h). Research on the transfer material to obtain mycelium on granular support at the Agaricus blazei Murrill mushrooms, Scientific works - Agronomy series, USAMV Iași, vol. 59(2), 231-236.

Rózsa S., Lazăr V., Gocan Tincuța-Marta, Rózsa Melinda, Poșta G. (2017b). Interaction between growing substrate nitrogen content and Agaricus blazei Murrill mushrooms protein content, Lucrări Științifice - Seria Horticultură, USAMV Iași, Volume 60 (2), 123-130.

Rózsa, S., Dănuț M.N., Gocan, T. M., Sima, R., Lazăr, V., Rózsa, M. (2017c). Influence of temperature and relative humidity on the studded Agaricus blazei Murrill mushroom compost, Current Trends in Natural Sciences, 6(12), 111-118.

Rózsa, S., Dănuț M.N., Gocan, T.M., Sima, R., Andreica, I., Rózsa, M. (2017d). Agaricus blazei Murrill mushroom compost study anaerobic and aerobic phases. Current Trends in Natural Sciences, 6(12), 75-82.

Rózsa, S., Dănuț M.N., Gocan, T.M., Sima, R., Andreica, I., Rózsa, M. (2017e). Mycelial biomass production of the Sun mushroom (Agaricus blazei Murrill), Current Trends in Natural Sciences, 6(12), 126-130,

Rózsa, S., Gocan, T.-M., Lazăr, V., Andreica, I., Rózsa, M., Măniuțiu, D.-N., \& Sima, R. (2017f). The Effect of Processing on Chemical Constituents of Agaricus spp. Mushrooms. Notulae Botanicae Horti Agrobotanici ClujNapoca, 45(2), 507-516. https://doi.org/10.15835/nbha45210764.

Wang, S.Y. and Shiao M.S. (2000). Pharmacological Functions of Chinese Medicinal Fungus Cordyceps sinensis and Related Species: Journal of Food and Drug Analysis Vol. 8 No. 4, 248-257.

Xiao, J.H., Zhong, J.J. (2007). Secondary metabolites from Cordyceps species and their antitumor activity studies. Recent Pat Biotechnol. 1(2), 123-37.

Yang, Y.Z., Wang, L.S., Deng, H.Y. (1994). Short-term observation of treating chronic hepatitis B and post-hepatitis cirrhosis with XinGanBao. Research of Chinese Materia Medica. 1, 19-20.

Zhu, J.S., Halpern, G.M. and Jones K. (1998). The scientific rediscovery of an ancient Chinese herbal medicine: Cordyceps sinensis: part I and II. J. Alternative \& Complementary Med. 4, 289-303, 429-457. 